\title{
Energy Biomass from Large Rangeland Shrubs of the Intermountain United States
}

\author{
GORDON A. VAN EPPS, JERRY R. BARKER AND C.M. MCKELL
}

\section{Abstract}

Large individual plants within a few species of rangeland shrubs were studied in several Intermountain States for their potential use in establishing biomass fuel energy plantations. Their locations were based on reports in the literature, suggestions from various range researchers, and personal knowledge. Biomass and other shrub physical characteristics plus site data were recorded for big sagebrush (Artemisia tridentata), fourwing saltbush (Atriplex canescens), big saltbush (A. lentiformis), greasewood (Sarcobatus vermiculatus), rubber rabbitbrush (Chrysothamnus nauseosus), and spreading rabbitbrush (C. linifolius) in 34 locations. Samples of current year's growth and woody tissue were analyzed for burning qualities (heat of combustion, sulfur, moisture, and ash content). Greatest biomass per plant of the individuals sampled was found in greasewood with fourwing saltbush, rubber rabbitbrush, and sagebrush following in decreasing order. Burning qualities varied among the species analyzed. The heat of combustion of the woody material from all shrubs was approximately $4500 \mathrm{Kcal} / \mathrm{kg}$, but current year's growth varied considerably among species.

Numerous investigators are considering woody plants as a renewable resource for energy. Most of the studies a re related to forest lands and more specifically to those producing deciduous trees. Blankenhorn et al. (1978) reporting on a natural forest biomass site in Pennsylvania have determined that the electrical energy produced from burning biomass would be about $8 \%$ greater than the sum of all input energy. In California the feasibility of using cha parral as a renewable energy resource was considered in a seminar by the Pacific Southwest Forest and Range Experiment Station (1976). Part of the incentive for using chaparral would be a reduction in fire hazard.

As alternative energy sources are examined for their feasibility, it is logical to ask if highly productive native shrubs growing on millions of acres of arid and semiarid rangelands of the western United States have a potential for use as energy fuel from their biomass. Although uncertainties exist in producing woody biomass for energy fuels, arid lands shrubs offer several advantages that may be very favorable (Cox 1979). Shrubs could be grown on marginal crop lands and multiple-use rangelands; they would offer little or no competition for irrigation water; generally shrubs have but little need for fertilizer application; and within the wide diversity of native shrubs a number of species have a potential for relatively large biomass production on various soil conditions. To obtain the most favorable biomass production potential, large biotypes of range shrubs were targeted for study.

Various reports have indicated that large individual shrubs or even populations of large plants have developed under favorable site conditions. For a period of years the Society for Range Management maintained a committee to receive and publish reports of

\footnotetext{
Authors are associate professor (stationed at Snow Field Station Ephraim, Utah 84627), graduate research assistant and professor, Range Science Department and Institute for Land Rehabilitation, Utah State University, Logan, Utah 84322. Authors acknowledge the assistance of Eric Christensen and Robert Otsyina. The work was supported by the Department of Energy (Contract DOE/ET/20193), Utah Agricultural Experiment Station, and Snow College.

Manuscript received March 14, 1980.
}

giants shrubs. Pase reported finding a very large sagebrush (Artemisia tridentata) east of Kanab, Utah (1956); Nord declared he found a prize bitterbrush Purshia tridentata in Lassen County, California (1962), but Driscoll found an even larger bitterbrush (1963). Schneegas and Nord (1967) claimed to top the list with a monarch-size big sagebrush. Other reports of shrubs and their biology are included in publications edited by McKell et al. (1972) and Stutz et al. (1975).

The research reported in this paper is phase one of a two-phase project. The objectives of this phase were to locate large shrubs within natural shrub populations, measure their standing biomass, density, and burning quality relative to their potential use in establishing shrub energy plantations. Also, to provide background information on soil and site conditions, the soil surface was sampled in areas where the large plants were located.

\section{Methods}

Individual plants were selected for this study on the assumption that they would express a genetic ability to grow large and at a faster rate than the norm for the species. On the basis of this assumption, we shall refer to these large plots as biotypes within the shrub populations which, according to Stebbins (1950), are plants of a given genotype. Such large biotypes would be valuable if they would be capable of suprior growth under arid conditions with but a minimum of management on various soil types. Currently research is in progress to test the assumption that large shrubs are genetically and physiologically different from smaller plants in adjacent areas.

Shrub species chosen for study were fourwing saltbush (Atriplex

Table 1. Locations where giant shrubs were reported growing. Areas were subsequently visited for observations, measurements, and collection of seeds or propagation material.

\begin{tabular}{ll}
\hline Utah & Nevada \\
\hline Nephi Canyon & Wells \\
Jericho Sand Dunes & New Pass \\
Callao Road & Fallon \\
Maeser & Quail Canyon \\
Davis Spring Road & Palmetto Wash \\
Huntington & Willow Creek \\
Johnson Canyon & Pyramid Lake \\
Nephi Field Station & Horse and Cattle Conservation \\
Antimony & Range \\
Monticello & Cold Spring \\
San Rafael Swell & Colorado \\
St. George & Little Dolores Canyon \\
Island Park & Dove Creek \\
Colo-Utah Border, Hwy. 650 & Rangely \\
Henrieville & Meeker \\
Wyoming & Idaho \\
Buffalo Bill Reservoir & Fourth of July Canyon \\
Rock Springs & Bruno \\
Black Rock Butte & \\
Upper Slide Lake & \\
\hline
\end{tabular}


canescens), big saltbush (A. lentiformis), big sagebrush (Artemisia tridentata), spreading rabbitbrush (Chrysothamnus linifolius), rubber rabbitbrush (C. nauseosus), and greasewood (Sarcobatus vermiculatus). All are common to the cold deserts of the Intermountain states. Over 36 sites in Utah and the adjacent states were visited in the spring and summer of 1978 (Table 1). Possible study and collection sites for the large shrub biotypes were obtained from published records and from recommendations of range scientists ${ }^{1}$.

At each site, three to five specimens of the largest plants were measured and harvested. Plant height, plant cover, canopy thickness, stem basal circumference, and plant biomass were measured for each plant. Stem basal circumference is the total length around the stem or stems of the plant at ground level. Species such as greasewood, rabbitbrush and fourwing saltbush usually have multiple stems. Total plant biomass was separated into current year's growth and woody material. Also, the mean area occupied by each large plant and its nearest neighbors was determined by measuring height and ground cover. However, only shrubs were considered as nearest neighbors. In addition, qualitative factors such as phenology, growth habit, and plant vigor were assessed

Samples of current year's growth and woody tissues were obtained from each shrub collected. These were oven dried, weighed, and laboratory tested for heat of combustion, percent moisture, ash, and sulfur (Chapman and Pratt 1961, American Society for Testing materials 1966).

At each site, a composite sample of surface soil ( $15 \mathrm{~cm}$ deep) was collected. Five to eight samples were put in a paper sack and thoroughly mixed and from this a portion was kept for laboratory analyses. Soil texture, $\mathrm{pH}$, salinity and several fertility parameters were determined at the Utah State University Soil Testing Laboratory using standard procedures.

Authors thank Elbert Baese, James Luster, E. Durant McArthur, John C. Likins, A Perry Plummer, Howard C. Stutz, Arthur L. Tait, Paul T. Tueller, Min Hironaka, A. Alan Beetle, and Neil E. West for their assistance in sending information and maps of big shrub locations they had seen in years of field work.

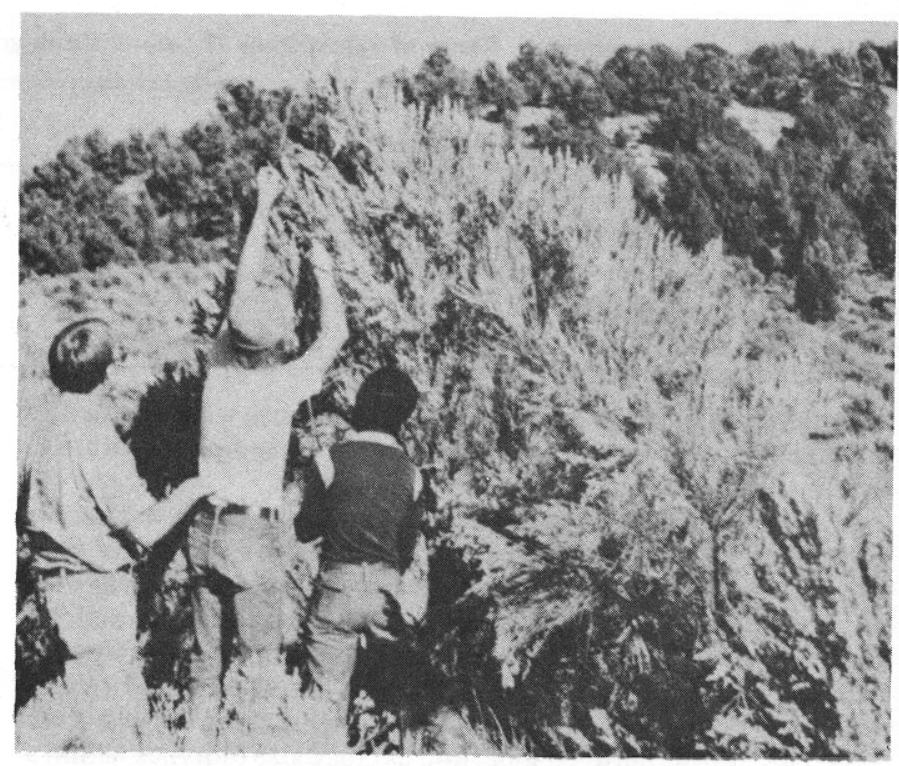

Fig. 1. A large sagebrush plant being measured for biomass characteristics.

\section{Results}

Characteristically, within a given shrub community, largerthan-average shrubs can be found growing on favorable sites (Fig. 1). Favorable sites represent areas which for some edaphic and / or topographical reason receive more moisture and have deep soils to sustain plant growth. Such areas include swales, gullies, deep alluvial soils, etc.

The size and biomass of the large shrubs varied among sites (Table 2). In addition, there were obvious differences among spe-

Table 2. Mean size, standing biomass, and stand density for six shrubs at various locations in the Intermountain area. Each mean is the average of three plants. Values in parentheses are provided for a comparison with the size of average plant.

\begin{tabular}{|c|c|c|c|c|c|}
\hline Species site & $\begin{array}{l}\text { Height } \\
(\mathrm{m})\end{array}$ & $\begin{array}{l}\text { Cover } \\
\left(\mathrm{m}^{2}\right)\end{array}$ & $\begin{array}{l}\text { Stem basal } \\
\text { circumference } \\
(\mathrm{cm})\end{array}$ & $\begin{array}{l}\text { Total biomass per } \\
\text { plant (ovendry) } \\
(\mathrm{kg})\end{array}$ & $\begin{array}{l}\text { Stand density } \\
\left(\mathrm{No} / 10 \mathrm{~m}^{2}\right)\end{array}$ \\
\hline \multicolumn{6}{|l|}{ Big sagebrush } \\
\hline Little Dolores Canyon & 2.7 & 1.2 & 39.7 & 5.5 & 9.1 \\
\hline Maeser & $3.2(.82)$ & $3.5(.5)$ & 53.0 & $13.6(2.2)$ & 2.4 \\
\hline Buffalo Bill Reservoir & $2.3(1.1)$ & $3.8(.9)$ & 62.7 & $15.9(2.1)$ & 1.3 \\
\hline Black Rock Butte & $2.0(0.8)$ & $2.8(.3)$ & 51.3 & $13.8(0.9)$ & 7.7 \\
\hline Antimony & $(0.9)$ & $(.1)$ & & (1.1) & \\
\hline \multicolumn{6}{|l|}{ Big saltbush } \\
\hline Cold Springs & 1.9 & 5.6 & - & 17.5 & - \\
\hline St. George & 2.2 & 7.8 & 160.0 & 30.5 & 1.5 \\
\hline Quail Canyon & 2.0 & 7.5 & 148.0 & 17.5 & 5.2 \\
\hline \multicolumn{6}{|l|}{ Fourwing saltbush } \\
\hline Jericho Sand Dunes & 2.2 & 16.5 & 465.0 & 38.7 & - \\
\hline Utah-Colo Border & 1.6 & 9.7 & - & 16.7 & 1.3 \\
\hline Kanab & 1.5 & 5.2 & 147.7 & 12.0 & 2.8 \\
\hline St. George & 1.7 & 11.7 & 209.3 & 33.6 & 1.4 \\
\hline \multicolumn{6}{|l|}{ Greasewood } \\
\hline Davis Spring Road & 2.4 & 9.1 & 186.7 & 44.8 & 2.1 \\
\hline Monticello & 2.9 & 8.0 & 150.3 & 34.7 & 2.3 \\
\hline Palmetto & 2.4 & 7.0 & 235.3 & 38.6 & 3.2 \\
\hline \multicolumn{6}{|l|}{ Rubber rabbitbrush } \\
\hline Huntington & 1.8 & 5.7 & - & 3.1 & 2.2 \\
\hline Palmetto & 2.4 & 7.5 & 164.7 & 16.7 & 2.8 \\
\hline Antimony & 1.9 & 3.1 & 73.3 & 12.0 & 2.6 \\
\hline Monticello & 1.7 & 8.3 & 80.0 & 33.6 & 2.9 \\
\hline Johnson Canyon & $(1.0)$ & (1.1) & & $(1.2)$ & \\
\hline \multicolumn{6}{|l|}{ Spreading rabbitbrush } \\
\hline Henrieville & 1.7 & 2.3 & 58.7 & 9.3 & 20.4 \\
\hline Nephi Field Station & 1.6 & 4.8 & 110.7 & 25.6 & 1.2 \\
\hline
\end{tabular}


Table 3. Soil analysis summary. Range of values from 32 natural shrub growing sites.

\begin{tabular}{lccccc}
\hline Species & Number of sites & pH & $\begin{array}{l}\text { ECe } \\
\text { (mmhox/cm) }\end{array}$ & $\begin{array}{l}\text { CEC } \\
\text { (meq/ 100 g) }\end{array}$ & Soil class \\
\hline Big sagebrush & 11 & $7.2-7.7$ & $0.3-1.5$ & $2.8-21.5$ & Sand-silt loam \\
Fourwing saltbush & 7 & $7.0-8.2$ & $0.4-1.1$ & $3.7-20.2$ & Sand-silt loam \\
Greasewood & 3 & $7.9-9.5$ & $0.7-5.9$ & $7.2-17.1$ & Sandy loam-clay loam \\
Rubber rabbitbrush & 6 & $7.5-7.9$ & $0.4-1.7$ & Sand-clay loam & Loamy sand silt loam \\
Spreading rabbitbrush & 2 & $7.3-7.7$ & $0.4-0.8$ & $6.1-21.5$ & Sandy loam \\
Big saltbush & 3 & $7.5-8.3$ & $0.8-3.1$ & $3.7-14.7$ & \\
\hline
\end{tabular}

cies in size and biomass production. Big sagebrush was consistently the tallest among the species sampled and spreading rabbitbrush was the shortest.

In comparison with regular-size plants, large sagebrush plants were twice as tall and more than 3 times greater in cover than normal sized plants. Biomass production of large plants was over six times greater than average ones. However, fourwing and big saltbush had the greatest ground cover and stem basal circumference whereas big sagebrush had the least. Large plants of greasewood provided the most biomass while large sagebrush yielded the least. Differences between large and average size biotypes within a species at any given location appeared to be associated with site favorability.

The stand density of big sagebrush and greasewood was greater for stands of the smaller sized shrubs than for the larger shrubs (Table 2). Plants may compensate for a smaller size with a greater density to obtain an optimum biomass per unit area. Further research is needed to clarify the relationship of shrub biomass production to density. These data can be used only as a comparison at this time and for the conditions described.

Soil chracteristics at the native growth site were more uniform than expected (Table 3) and are presented here to show the range of values that would be encountered in a biomass production pro- gram. Surface soil $\mathrm{pH}$ was basic at all sites. Values varied from 7.0 to 9.5. As expected, greasewood was found growing on the most alkaline soils. The electrical conductivity values varied from 0.3 to $5.9 \mathrm{mmhos} / \mathrm{cm}$. The higher electrical conductivity values under which greasewood and big saltbush were growing was lower than expected as these species are normally found growing on highly alkaline soils. Values of electrical conductivity at these levels would be inhibitory to the growth of most crop plants (Maas and Hoffman 1977). Soils on which greasewood plants were growing exhibited a range of va riability in salinity whereas soils under spreading rabbitbrush were relatively uniform. The soil cation exchange capacity (CEC) of shrub study sites was highly variable. Values ranged from 2.8 to $21.5 \mathrm{meq} / 100 \mathrm{~g}$. The soil textural classes where large biotypes of big sagebrush were growing showed the greatest variation, whereas greasewood soil was least variable. The surface soil texture was generally a sandy loam at all sites. Field observations indicate that spreading rabbitbrush may require more soil moisture than the other species.

The burning quality of arid land shrubs was generally uniform with plants of the same species but among species the values were different from each other (Table 4). Regardless of species, percent ash, sulfur, and moisture were consistently lower for the woody material than for the current year's growth. Greasewood had the

Table 4. Burning quality of five cold-desert shrubs from various locations through the Intermountain area. Each value is the average of three or more plants except the grand mean for each species.

\begin{tabular}{|c|c|c|c|c|c|c|c|c|}
\hline \multirow[b]{2}{*}{ Site } & \multicolumn{2}{|c|}{ Ash } & \multicolumn{2}{|c|}{ Sulfur } & \multicolumn{2}{|c|}{ Moisture } & \multicolumn{2}{|c|}{ Heat of combustions } \\
\hline & $\begin{array}{c}\text { Woody } \\
(\%)\end{array}$ & $\begin{array}{c}\text { Annual } \\
(\%)\end{array}$ & $\begin{array}{c}\text { Woody } \\
(\%)\end{array}$ & $\begin{array}{c}\text { Annual } \\
(\%)\end{array}$ & $\begin{array}{c}\text { Woody } \\
(\%)\end{array}$ & $\begin{array}{c}\text { Annual } \\
(\%)\end{array}$ & $\begin{array}{l}\text { Woody } \\
\left(\mathbf{K c a l} / \mathbf{K}_{\mathbf{g}}\right)\end{array}$ & $\underset{\text { (Kcal/Kg) }}{\text { Annual }}$ \\
\hline \multicolumn{9}{|l|}{ Big sagebrush } \\
\hline Little Dolores & 3.1 & 6.8 & 0.04 & 0.18 & 28.6 & 55.9 & 4567 & 4729 \\
\hline Maeser & 3.0 & 6.5 & 0.04 & 0.19 & 22.0 & 55.4 & 4723 & 4735 \\
\hline Buffalo Bill & 3.2 & 6.8 & 0.02 & 0.14 & 26.6 & 55.9 & 4683 & 4640 \\
\hline Black Rock & 3.2 & 6.8 & 0.01 & 0.17 & 22.8 & 56.8 & 4586 & 4688 \\
\hline Mean & 3.1 & 6.7 & 0.03 & 0.17 & 25.0 & 56.0 & 4639 & 4698 \\
\hline \multicolumn{9}{|c|}{ Fourwing saltbush } \\
\hline Jericho & 2.5 & 9.9 & 0.05 & 0.03 & 24.9 & 64.2 & 4542 & 4358 \\
\hline Utah-Colo. & 3.5 & 9.9 & 0.10 & 0.51 & 43.3 & 52.3 & 4487 & 4292 \\
\hline Callao Road & 3.5 & 9.9 & 0.10 & 0.51 & 20.4 & 55.5 & 4486 & 4292 \\
\hline Mean & 3.5 & 9.9 & 0.08 & 0.35 & 29.5 & 57.3 & 4505 & 4314 \\
\hline \multicolumn{9}{|l|}{ Greasewood } \\
\hline Davis Spring & 1.6 & 19.8 & 0.18 & 0.42 & 27.7 & 71.9 & 4708 & 3680 \\
\hline Palmetto & - & - & - & - & 48.1 & 62.1 & 4699 & 3837 \\
\hline Monticello & 1.8 & 20.6 & 0.30 & 0.50 & 26.2 & 67.3 & 4772 & 3481 \\
\hline Mean & 1.7 & 20.2 & 0.24 & 0.46 & 34.0 & 67.1 & 4726 & 3666 \\
\hline \multicolumn{9}{|c|}{ Rubber rabbitbrush } \\
\hline Huntington & 2.8 & 7.6 & 0.04 & 0.18 & 53.0 & 62.5 & 4623 & 4837 \\
\hline Monticello & 2.5 & 7.2 & 0.03 & 0.21 & 50.0 & 53.8 & 4535 & 4767 \\
\hline Palmetto & - & - & - & - & 27.2 & 45.0 & 4808 & 4878 \\
\hline Antimony & - & - & - & - & 48.6 & 58.7 & 4745 & 4815 \\
\hline Mean & 2.7 & 7.4 & 0.04 & 0.20 & 44.7 & 55.0 & 4678 & 4832 \\
\hline \multicolumn{9}{|c|}{ Spreading rabbitbrush } \\
\hline Nephi F.S. & - & - & - & - & 56.1 & 59.9 & 4505 & 4421 \\
\hline Henrieville & - & 一 & - & - & 49.2 & 58.4 & 4613 & 4537 \\
\hline Mean & & & & & 52.7 & 59.2 & 4559 & 4479 \\
\hline
\end{tabular}

'Annual refers to current year's growth. 
Table 5. Estimated yield and energy potential for big sagebrush, fourwing saltbush, greasewood and rabbitbrush. Calculations are based on the highest yielding site as reported in Table 2.

\begin{tabular}{|c|c|c|c|c|}
\hline Species & $\begin{array}{l}\text { Average plant biomass } \\
\text { (dryweight) } \\
\text { (kg/plant) }\end{array}$ & $\begin{array}{l}\text { Plant density in nature' } \\
\text { (no./ ha) }\end{array}$ & $\begin{array}{l}\text { Estimated potential yield } \\
\qquad(\mathrm{kg} / \mathrm{ha})\end{array}$ & $\begin{array}{l}\text { Estimated energy potential } \\
\text { (Kcal/ha) }\end{array}$ \\
\hline Big sagebrush & 15.9 & 1316 & 20,924 & $97,900,000$ \\
\hline Fourwing saltbush & 33.6 & 292 & 9,811 & $44,400,000$ \\
\hline Greasewood & 44.8 & 2174 & 97,395 & $458,500,000$ \\
\hline Rubber rabbitbrush & 29.0 & 2632 & 76,328 & $366,900,000$ \\
\hline
\end{tabular}

I Space plantings at field station or production fields could markedly increase plant density.

lowest percent ash in woody material but the highest percent ash in current year's growth compared with the other species. The high percent ash in current year's growth may adversely influence the burning quality of this type of material. Nord found that a high ash content in Atriplex leaves tended to impart a slow burning cha racter to it (Nord and Countryman 1972). Among the six shrub species, big sagebrush was the lowest in percent ash. Percent sulfur was lowest in big sagebrush and highest in greasewood. Big sagebrush also had the lowest percent moisture while spreading rabbitbrush had the highest. Heat produced from the combustion of woody and annual material was about the same for each species except greasewood. Combustion of greasewood annual growth produced less heat than the woody material.

Although present field data and laboratory results (Table 5) are limited, they provide a preliminary estimate of biomass production and energy potentials for four rangeland shrubs. Rubber rabbitbrush and greasewood have the greatest potential for higher energy production because of their ability to grow in dense stands and still have relatively high individual plant biomass yield. Under natural conditions, fourwing saltbush does not grow as dense as other shrubs. However, with minimal management, fourwing saltbush plant densities could be greatly increased in spaced plantings. Big sagebrush could also be grown in dense stands but in the locations studied its individual plant biomass was not as great as that of the other species. Being a root and stem sprouter, spreading rabbitbrush could develop a dense ground cover in a few years.

The potential for energy biomass production of these shrubs may be increased with minimal management. A possible strategy in planning for production of biomass from shrubs in semiarid regions would be to grow genetically superior plants in spaced plantings to optimize the use of soil moisture. Thus, high stand density could be achieved but only under conditions of optimum spacing in field plantings. Lipinsky and Kresovich (1979) have reported several important concepts in a biomass system approach for arid land environments.

\section{Summary and Conclusion}

At selected sites populations of large shrubs were studied in the Intermountain area as to their suitability as a possible source of energy fuel from biomass. Locations where shrubs of various species were reported to grow were selected for study on the basis of recommendations of range research workers and personal observations. Three to five individual plants of a given species were harvested to determine standing biomass and burning quality. Results showed that the heat of combustion of natural shrubs varied from 3600 to $4800 \mathrm{Kcal} / \mathrm{kg}$ depending on the species and portion of plant burned. Greasewood and rubber rabbitbrush have a high energy potential per hectare because of their ability to grow in dense stands and still produce a relatively high individual plant biomass.

Many uncertainties exist in producing biomass for energy fuels. However, arid land shrub biomass production offers several advantages that may be more favorable than other biomass types. Shrubs could be planted to utilize available marginal croplands and rangelands. With minimal management there would be little or no competition for scarce water resources. Furthermore, within the wide diversity of native shrubs, a number of species could be utilized. Further research will help document the potential for rangeland energy production as an additional multiple use inasmuch as grazing and recreation could still be possible as a use prior to the harvest of shrubs for biomass.

\section{Literature Cited}

American Society for Testing Materiak. 1966. Method of test for grass calorific value of solid fuel by adiabatic bomb calorimetry. D 2015-66. Philadelphia, $\mathbf{P a}$.

Blankenhor, Paul R., Todd W. Bowersox, James J. Hillebrand, and Wayne K. Murphey. 1978. Evaluation procedure for consideration of forest biomass as a fuel source for a 100 megawatt electric generating facility. Penn. State Agr. Exp. Sta. Bull. 820. 16 p.

Chapman, H.D., and P.R. Pratt. 1961. Methods of analysis for soils, plants and waters. Univ. of California, Div. Agr. Sci.

Cox, L.M. 1979. Searching for energy in self-made monsters. Utah State Univ. College of Natur. Resources. Edge 2:26-27.

Driscoll, R.S. 1963. A larger bitterbrush. J. Range Manage. 16:82-83.

Lipinsky, Edward S., and Stephen Kresovich. 1979. Fuels from biomass systems for arid land environments. Arid Land Plant Resources (edited by J.R. Goodin and David K. Northington, Internat. Center for Arid and Semi-arid Land Studies). Texas Tech. Univ. p. 294-306.

Maas, E.V., and G.J. Hoffman. 1977. Crop salt tolerance: current assessment. Proc. Amer. Soc. Civil Eng. 103 (IR2):115-134.

McKell, C.M., J.P. Blaisdell, and J.R. Goodin (eds.). 1972. Wildland shrubs - their biology and utilization. U.S. Dep. Agr. Forest Serv. Gen. Tech. Rep. INT-1. 494 p.

Nord, E.C. 1962. Was this a prize bitterbrush? J. Range Manage. 15:82-83. Nord, E.C., and C.M. Countryman. 1972. Fire relations. p. 88-97 In:C.M. McKell, J.P. Blasidell and J.R. Goodin eds. Wildland Shrubs-Their Biology and Utilization. USDA Forest Service Gen. Tech. Rep. INT-1.

Pacific Southwest Experiment Station and Angeles National Forest (sponsors). 1976. Chaparral for energy information exchange. $170 \mathrm{p}$.

Pase, C.P. 1956. Is this the largest sagebrush plant? J. Range Manage. 9:60. Schneegas, E.R., and E.C. Nord. 1967. The monarch big sagebrush of White Mountain. J. Range Manage. 20:51-52.

Stebbins, G. Ledyard. 1950. Variation and evolution in plants. Columbia Univ. Press. New York. 643 p.

Stutz, H.C., J.M. Melby, and G.K. Livingston. 1975. Evolutionary studies of Atriplex; a relic gigas diploid population of Atriplex canescens. Amer. J. Bot. 62(3):236-245. 